\title{
Cross-cultural adaptation and validation of the Intermittent Self- Catheterization Questionnaire
}

\author{
Adaptação transcultural e validação do Intermittent Self-Catheterization Questionnaire
}

Raelly Ramos Campos Ximenes ${ }^{1}$, Zuila Maria de Figueiredo Carvalho ${ }^{2}$, Janaína Fonseca Victor Coutinho² ${ }^{2}$ Deyse Cardoso de Oliveira Braga² ${ }^{2}$ Joyce Miná Albuquerque Coelho², Rita Mônica Borges Studart ${ }^{3}$

Objective: to adapt cross-culturally and validate the contents of the Intermittent Self-Catheterization Questionnaire for Portuguese language. Methods: methodological study involving cross-cultural validation, conducted in five phases: initial translation, translation synthesis, back-translation to the source language, review by committee of judges, pre-test of final version with 30 people with traumatic spinal cord injury who performed auto-catheterization and content validation with 17 judges. Results: changes were made in the Portuguese version of the Intermittent Self-Catheterization Questionnaire regarding the semantic, idiomatic, experimental and conceptual aspects. The pre-test revealed that the items of the translated and adapted version were easy to understand and interpret. The Content Validation Index was 0.92. Conclusion: the translated version of the Intermittent Self-Catheterization Questionnaire was transculturally adapted to Brazilian Portuguese language and validated with a satisfactory content validation index, being considered valid to verify the quality of life of people with neurological conditions that perform urinary auto-catheterization.

Descriptors: Translating; Validation Studies; Spinal Cord Injuries; Urinary Catheterization; Nursing.

Objetivo: adaptar transculturalmente e validar o conteúdo do Intermittent Self-Catheterization Questionnaire para língua portuguesa. Métodos: estudo metodológico envolvendo a validação transcultural, conduzido em cinco fases: tradução inicial, síntese da tradução, tradução de volta à língua original, revisão por comitê de juízes, pré-teste da versão final, com 30 pessoas com lesão medular traumática que realizavam autocateterismo, e a validação de conteúdo com 17 juízes. Resultados: foram realizadas alterações na versão em português do Intermittent Self-Catheterization Questionnaire quanto ao aspecto semântico, idiomático, experimental e conceitual. 0 pré-teste revelou que os itens da versão traduzida e adaptada eram de fácil compreensão e interpretação. O Índice de Validação de Conteúdo foi 0,92. Conclusão: o Intermittent Self-Catheterization Questionnaire, versão traduzida foi adaptado transculturalmente para o português brasileiro e validado com Índice de Validação de Conteúdo satisfatório, sendo considerado válido para verificar a qualidade de vida das pessoas com afecções neurológicas que realizam autocateterismo urinário.

Descritores: Tradução; Estudos de Validação; Traumatismos da Medula Espinhal; Cateterismo Urinário; Enfermagem.

\footnotetext{
${ }^{1}$ Hospital Universitário Walter Cantídio. Fortaleza, CE, Brazil.

${ }^{2}$ Universidade Federal do Ceará. Fortaleza, CE, Brazil.

${ }^{3}$ Universidade de Fortaleza. Fortaleza, CE, Brazil. 


\section{Introduction}

Spinal cord injury can occur from the foramen magnum to the cauda equina. In the case of damage to the cervical spine, tetraplegia occurs, and when the lesion affects the thoracic, lumbar or sacral segments, paraplegia occurs ${ }^{(1)}$.

The incidence rate of traumatic spinal cord injury in the Americas ranges from 20.7 to 83.0 persons per million inhabitants per year, based on the analysis of publications from 1950 to $2012^{(2)}$. In Brazil, the mean incidence of spinal cord trauma is 21 cases per million per year, of which falls from height are the most common cause ${ }^{(3)}$.

Among the lesions caused by spinal cord injury there is the neurogenic bladder, characterized by urinary tract dysfunction that can lead to incontinence, renal failure, infection and nephrolithiasis. Such complications constitute significant causes of morbidity and mortality among people with spinal cord injury $^{(4-6)}$.

Neurogenic bladder management involves, for most people, intermittent bladder catheterization, a procedure that requires scientific knowledge and technical ability, since it is not free of complications. The patient or caregiver can also perform catheterization after receiving guidelines and training of nurses, however, this technique requires actions directed to the reality of each patient with regard to social conditions, handling, storage and technique of catheter passageway. In addition, these factors interfere in the quality of life of people with spinal cord injury ${ }^{(7-8)}$.

Thus, the actions of nurses should go beyond the performance of the technique and the provision of guidelines regarding the use of the catheter, and should understand the repercussion of this clinical situation in the lives of people with spinal cord injury. In this sense, the use of appropriate measurement tools assists nurses and other health professionals in conducting appropriate patient care.

Specifically for people with neurological conditions that perform urinary auto-catheterization, En- glish researchers have developed an instrument for assessing quality of life, called the Intermittent Self-Catheterization Questionnaire (ISC-Q) ${ }^{(9)}$.

The ISC-Q has 24 items covering four domains: ease of use (eight), comfort (four), discretion (six) and psychological well-being (six). Answers are given through a Likert scale with the following response options: (1) I totally disagree; (2) I partially disagree; (3) I neither agree nor disagree; (4) I partially agree; and (5) I totally agree.

The incorporation of this instrument in the care practice may direct individual interventions, contribute to care planning and, consequently, favor health promotion of people with neurological conditions that perform urinary catheterization. Therefore, the objective was to adapt cross-culturally and validate the content of ISC-Q to Portuguese language.

\section{Methods}

This is a methodological study involving translation and cultural adaptation of the ISC-Q to the Brazilian context. The methodological procedures followed five phases: initial translation, translation synthesis, back-translation, review by a committee of judges and pre-testing of the final version ${ }^{(10)}$. The translation and adaptation process was initiated after authorization of the main author of the instrument via electronic mail.

In the first phase, the initial translation consisted of the translation of the English language into the Portuguese language by two bilingual Brazilian translators, with mastering of the English language. The first translator was from the health area (a nurse) and was informed about the objectives of the study in order to obtain equivalence from a clinical perspective. The second translator was a journalist and was not informed about the research objectives.

In the second phase, the synthesis of translations was carried out by a third person (an English teacher) who had the role of mediating discussions and differences between the translations of the first 
and second translators. This third translator had not participated in the previous stage of the translation and adaptation process and was therefore considered impartial and able to prepare the synthesized version of the two versions.

The back-translation, third phase, consisted in the translation of the synthesized version of the two previous versions back to the source language. Two English-speaking bilingual translators were invited, one native from Plymouth, Massachusetts, USA, responsible for back-translation 1 , and another from Raleigh, North Carolina, USA, responsible for back-translation 2. The back-translations 1 and 2 were totally blind to the original version and to the concepts of the construct.

In the fourth phase, a committee of judges reviewed the adaptation. It included five professionals selected through the Lattes Platform according to the following criteria: clinical experience and/or research in the neurological area, in quality of life and self-catheterization, as well as in translation, adaptation and validation studies in scales, all of them being nurses. The material for the analysis of equivalences was handed in person, and the judges were advised to individually evaluate and record impressions on the scale regarding semantic, idiomatic, experimental and conceptual equivalences. After this moment, a meeting was held with the judges in order to consolidate the versions and components of the questionnaire.

During the meeting, when one of the members of the committee differed in one item, other members offered and analyzed suggestions the in order to reach consensus that would foster the development of an instrument equivalent to the Brazilian culture. In order to facilitate the transcription of judges' speeches in a reliable way, the authors asked the participants for the permission to record them in audio, to which all of them agreed. At the end of the evaluation by the committee, the researcher analyzed the suggestions offered and proposed the final version of the instrument in the Portuguese language.

In the fifth phase, the pre-test, we could obser- ve the understanding of the instrument by the study population. The sample consisted of 30 adults with traumatic spinal cord injury who have undergone auto-catheterization.

Data collection for the pre-test occurred in the households of people with spinal cord injury in Fortaleza-Ceará, from August to September 2014. The participants were selected from the database of the Research and Extension Center in Neurological Nursing, linked to the Nursing Department of the Federal University of Ceará, which contained 132 people with registered spinal cord injury. The sample selection was made by convenience, being selected people living in Fortaleza, Brazil. The first contact with the participants was made through a telephone call in order to obtain the acceptance of participation in the research and to schedule the data collection. During the collection at the household, researchers applied a form with information that made it possible to delineate the sociodemographic profile and the Portuguese version of the ISC-Q. The application of the questionnaire lasted, on average, 40 minutes for each interviewee.

For better understanding, the evaluation of the sociodemographic profile data occurred through descriptive analysis, using the program Statistical Package for the Social Sciences version 19.0.

After completing the stages of translation and adaptation into Portuguese, another committee of specialized judges was created to carry out the content validation index, which evaluated their agreement on the representativeness of the measure in relation to the studied content. The content validation index is defined as the proportion of items that receive a score 3 or 4 by the judges, on a scale of 1 to $4^{(11)}$.

With the participation of up to five subjects, they should agree on the evaluation process of the items individually, so that the result is representative, and the value of the Content Validation Index (CVI) should be equal to 1 (I totally agree). In the case of six or more judges, it should reach a rate of not less than $0.78^{(12)}$.

For the selection of health professionals, we 
used the same selection criteria of the committee of judges of the fourth phase of translation and cultural adaptation. We invited 26 specialists by telephone and/or e-mail, through an invitation letter. Of these, 17 accepted to participate in the study, returning the answered questionnaire.

The study complied with the formal requirements contained in the national and international regulatory standards for research involving human beings

\section{Results}

The semantic, idiomatic, experimental and conceptual evaluation of ISC- $Q$ was crucial to evaluate the inconsistencies of previous translations. In this step, changes were made, which can be visualized in Figure 1. The expression "translated version" was added after the original name of the scale in English, for copyright reasons. Also, the word cateter (catheter) was replaced by sonda (probe) in all items, because in colloquial language, people who perform catheterization know the word cateter (catheter) as sonda (probe).

As for the changes in the items, there were substitutions of words and changes in the structure of the sentence: in item 2, the confused term was replaced by complicated; in item 4 , insertion by introduction; in item 5 , design by format, and insertion by introduction; in item 6, complicated by difficult. Regarding the structure of the sentence, in order not to avoid the conceptual content of item 2 , the sentence structure was changed: "I feel confident in my ability to use my catheter", in item 8, by "I rely on my ability to use the probe" (item 2). In section 9, the sentence structure was modified: "Storing catheters at home is inconvenient", by "Keeping my already used probe at home is inconvenient". Specifically in item 10, an addition was made at the end of the sentence to facilitate understanding: "Example: trips, tours". In item 13, the term "carry" was replaced by "take"; in item 15, the sentence structure "My catheter is discreet" was replaced by "No one notices my probe". In item 17 , the term "obvious" was changed to "perceived"; in item 20, the term "package" was excluded. The order of sentences was changed in items 1, 4, 6, 8, 9, 11, 12, 15, 18, 21, 22 and 23 , but we maintained the same meaning.

\begin{tabular}{|l|}
\hline Ease of use \\
\hline 1. When I need it, it is easy to prepare my probe. \\
\hline 2. It is complicated to prepare my probe to use it \\
\hline 3. It is easy to insert my probe \\
\hline 4. The introduction of my probe is sometimes uncomfortable \\
\hline 5. The format of my probe facilitates its introduction \\
\hline 6. It is difficult to use my probe \\
\hline 7. Probe lubrication makes it difficult to use it \\
\hline 8. I rely on my ability to use the probe \\
\hline Convenience \\
\hline 9. Keeping my already used probe at home is inconvenient \\
\hline 10. Taking the enough number of probes for a weekend is inconvenient \\
(Example: trips, tours) \\
\hline 11. It is inconvenient to carry enough probes for two weeks of vacation \\
\hline 12. When I am away from home, it is inconvenient to discard my probe \\
\hline Discretion \\
\hline 13. I find it easy to take enough probes with me on a daily basis \\
\hline 14. I find it easy to discard my probe when I am away from home. \\
\hline 15. No one notices my probe \\
\hline 16. I can use my probe discreetly when I am away from home \\
\hline 17. I can easily discard my probe without this being perceived by people \\
\hline 18. I feel confident with my probe when I am away from home \\
\hline Psychological well-being \\
\hline 19. I am aware of my need to perform self-catheterization \\
\hline 20. I would feel ashamed if people saw my probe \\
\hline 21. I feel uncomfortable with my need to use probe \\
\hline 22. I am worried if my probe will not empty my bladder completely \\
\hline $\begin{array}{l}\text { 23. Using a probe keeps me from visiting my friends and family as often as } \\
\text { I would like }\end{array}$ \\
\hline 24. I worry about the risk of long-term problems with using my probe \\
\hline
\end{tabular}

Figure 1 - Pre-final version of the Intermittent Self-Catheterization Questionnaire (ISC-Q)

Regarding the answers of each item, they should be marked according to the following options: I totally disagree, I partially disagree, I neither agree nor disagree, I partially agree and I totally agree. The options did not suffer changes in the transcultural translation and adaptation process.

The pre-test was performed with 30 partici- 
pants, of whom $63.3 \%$ were males, the mean age was 35 years, standard deviation of 11.9 years, $46.7 \%$ were singles, $40.0 \%$ married or in stable relationship, $13.3 \%$ were separated or divorced, $33.4 \%$ had up to nine years of schooling, $90.0 \%$ had up to 12 years of schooling and $9.9 \%$ had higher education, $56.7 \%$ did not work, $90.0 \%$ were retired and $56.7 \%$ referred receiving only one minimum wage.

Regarding the clinical characteristics, $40.0 \%$ of the spinal cord injuries occurred by firearm, 16.7\% by traffic accident, $10.0 \%$ by fall from height, 3.3\% by trampling and another $30.0 \%$ (involving post-surgical event, knife perforation, among other reasons).
Regarding the type of lesion, $86.7 \%$ were paraplegic. On the time since spinal cord injury, $70.0 \%$ had more than 5 years. On rehabilitation, $90.0 \%$ had performed it.

Regarding the application of the ISC-Q-translated version, the studied population did not indicate difficulties in understanding and interpreting the items. The instrument was considered simple and clear by $100.0 \%$ of the participants. However, items 10 and 11, 12 and 14 were considered as questions with similar contents.

Figure 2 shows the description of the Content Validation Index of the ISC-Q-translated version.

\begin{tabular}{|c|c|}
\hline Items & CVI \\
\hline Ease of use & 1 \\
\hline 1. When I need it, it is easy to prepare my probe & 1 \\
\hline 2. It is complicated to prepare my probe to use it & 0.82 \\
\hline 3. It is easy to insert my probe & 1 \\
\hline 4. The introduction of my probe is sometimes uncomfortable & 1 \\
\hline 5. The format of my probe facilitates its introduction & 0.70 \\
\hline 6. It is difficult to use my probe & 0.82 \\
\hline 7. Probe lubrication makes it difficult to use it & 0.94 \\
\hline 8. I rely on my ability to use the probe & 1 \\
\hline Convenience & 1 \\
\hline 10. Taking the enough number of probes for a weekend is inconvenient (Example: trips, tours) & 0.94 \\
\hline 11. It is inconvenient to take enough probes for two weeks of vacation & 0.29 \\
\hline 12. I find it easy to discard my probe when I am away from home. & 0.94 \\
\hline Discretion & 1 \\
\hline 13. I find it easy to take enough probes with me on a daily basis & 0.94 \\
\hline 14. I find it easy to discard my probe when I am away from home & 0.65 \\
\hline 15. No one notices my probe & 0.88 \\
\hline 16. I can use my probe discreetly when I am away from home. & 0.94 \\
\hline 17. I can easily discard my probe without this being perceived by people & 0.88 \\
\hline 18. I feel confident with my probe when I am away from home & 1 \\
\hline 19. I am aware of my need to perform self-catheterization & 1 \\
\hline 20. I would feel ashamed if people saw my probe & 1 \\
\hline 21. I feel uncomfortable with my need to use probe & 0.94 \\
\hline 22. I am worried if my probe will not empty my bladder completely & 1 \\
\hline 23. Using a probe keeps me from visiting my friends and family as often as I would like & 0.94 \\
\hline 24. I worry about the risk of long-term problems with using my catheter & 1 \\
\hline
\end{tabular}

Figure 2 - Content Validation Index (CVI) of the ISC-Q-translated versio 
The Content Validation Index ranged from 0.29 to 1 . Among the items that obtained the CVI below the recommended, there are the item 5 , with 0.70 ; item 11 , with the lowest index of the criteria, 0.29 ; and item 14 , with 0.65 . We obtained a general CVI of 0.92 . However, at this stage, we decided not to exclude any item, since other assessments of the psychometric properties of the instrument would still be necessary in other stages of the validation process.

\section{Discussion}

The study presented limitations regarding the selection of professionals to compose the committee of judges due to the specificity in the knowledge about the spinal cord injury and the practice of intermittent catheterization. It was also difficult to conduct the face-to-face stage with the committee of judges due to the difficulty of combining the date of the meeting in the participants' schedules. In addition, regarding the aspects related to the method itself, there was a limitation related to the subjectivity of the judges' opinion, reducing the capacity of inferences caused by the difficulty of consensus in the opinions, as well as by not performing the reliability stage, making it impossible to generalize results.

Offering a translated and adapted Portuguese version of the Intermittent Self-Catheterization Questionnaire, as well as the validation of its content, allows researchers and nurses to have an option of individual interventions and better care planning. Until then, there was no instrument in Portuguese language capable of measuring the quality of life of people with neurological conditions requiring self-catheterization.

In order to apply instruments from different cultures, not only translation from a linguistic point of view is needed, but also cultural adaption, given the specificity of some terms and their meaning in each culture and in the source language, in order to maintain the content validity of the instrument ${ }^{(13-14)}$.

However, the participation of judges allows spe- cific views that are added and complement each other. This integration allows the articulation between different knowledge and contributes to the elaboration of a pre-final version of the instrument with possibilities of use in another language ${ }^{(15)}$. On the other hand, the literature also reports absence of established criteria for the formation of the committee of judges and lack of consensus regarding the profile of this group of evaluators/judges ${ }^{(16)}$. In addition, the available methodological references are brief in their descriptions, not providing in-depth comments on their composition.

Regarding the socioeconomic variables, the findings of this study indicated that most participants were adult and male. Regarding the clinical characteristics, the episode that motivated the lesion occurred mostly due to firearm and with evolution to paraplegia, aspects corroborated by the literature ${ }^{(14,17)}$.

In sequence, the pre-test stage is relevant because it allows for the identification of possible errors, the understanding of the proposed questions and the practical aspects of the application, as well as the target population and the determination of the time of use of the instruments in practice ${ }^{(18)}$. At the time, the individual interview with the participants of the study gave them a moment to expose suggestions, in order to improve the understanding of the scale items.

In terms of content validation, the selection of the number and level of knowledge of experts is an essential step to ensure that the adapted instrument presents different interpretations. The content validation index of the translated version was close to 1 (0.92), a value considered excellent, since it shows that the specialists, in the majority, considered the instrument clear, understandable and relevant. However, three items presented values lower than those recommended by the literature, and therefore require further studies. Decisions on items (deleting, modifying or preserving) should not be based solely on empirical data. Thus, these actions should be subject to global analysis by the authors, depending on the intended objective, always based on the definition of the 
construct and analysis of the reliability and validity of the instrument ${ }^{(19-20)}$.

Finally, we suggest that the adapted instrument be evaluated for psychometric properties, so that the translation and adaptation process of the Intermittent Self-Catheterization Questionnaire is completed.

\section{Conclusion}

The Intermittent Self-Catheterization Questionnaire - translated version was transculturally adapted to Brazilian Portuguese with a satisfactory content validation index, presenting comprehension and concordance among the items and is apt to evaluate the quality of life of people with neurological conditions performing urinary self-catheterization.

\section{Collaborations}

Ximenes RRC contributed in conception and design, analysis and interpretation of the data, writing of the article and final approval of the version to be published. Carvalho ZMF contributed with conception and design, relevant critical review of the intellectual content and final approval of the version to be published. Coutinho JFV, Braga DCO, Coelho JMA and Studart RMB contributed with data analysis and interpretation and relevant critical review of intellectual content.

\section{References}

1. Nas K, Yazmalar L, Şah V, Aydın A, Öneş K. Rehabilitation of spinal cord injuries. World J Orthop. 2015; 6(1):8-16. doi: https://doi. org/10.5312/wjo.v6.i1.8

2. Furlan JC, Sakakibara BM, Miller WC, Krassioukov AV. Global incidence and prevalence of traumatic spinal cord injury. Can J Neurol Sci. 2013; 40(4):456-64. doi: https://doi.org/10.1017/ S0317167100014530
3. Botelho RV, Albuquerque LDG, Bastianello Junior $\mathrm{R}$, Arantes Júnior AA. Epidemiology of traumatic spinal injuries in Brazil: systematic review. Arq Bras Neurocir [Internet]. 2014 [cited 2018 Feb. 13]; 33(2):100-6. Available from: http://www. sbn.com.br/upload/user/files/16099_\%20 Arq\%20Bras\%20Neuro\%2033_2.pdf

4. Cardarelli WJ. Managed care aspects of managing neurogenic bladder/neurogenic detrusor overactivity. Am J Manag Care [Internet]. 2013 [cited 2018 Feb. 28]; $19(10$ Suppl):205-8. Available from: http://www.ajmc.com/journals/ supplement/2013/ace012_jul13_ngb/ace012_ jul13_ngb_cardarelli_s205to8

5. Taweel AW, Seyam R. Neurogenic bladder in spinal cord injury patients. Res Rep Urol. 2015; 7:85-99. doi: https://doi.org/10.2147/RRU.S29644

6. Welk B, Morrow SA, Madarasz W, Potter P, Sequeira $\mathrm{K}$. The conceptualization and development of a patient-reported neurogenic bladder symptom score. Res Rep Urol. 2013; 5:129-37. doi: https:// doi.org/10.2147/RRU.S51020

7. Campos CVS, Silva KL. Intermittent catheterization performed by home caregivers. Rev Min Enferm. 2013; 17(4):753-70. doi: https://doi. org/10.5935/1415-2762.20130056

8. Ercoles FE, Macieira TGR, Wenceslau LCC, Martins AR, Campos CC, Chianca TCM. Integrative review: evidences on the practice of intermittent/indwelling urinary catheterization. Rev Latino-Am Enfermagem. 2013; 21(1):459-68. doi: http://dx.doi. org/10.1590/S0104-11692013000100023

9. Pinder B, Lloyd AJ, Elwick H, Denys P, Marley J, Bonniaud V. Development and psychometric validation of the Intermittent Self-Catheterization Questionnaire. Clin Ther. 2012; 34(12):2302-13. doi: https://doi.org/10.1016/j.clinthera.2012.10.006

10. Beaton DE,Claire B, Francis G, Marcos BF.Guidelines for the process of cross-cultural adaptation of selfreport measures. Spine [Internet]. 2007 [cited 2018 Feb. 24]; 25(24):3186-91. Available from: http://www.dash.iwh.on.ca/sites/dash/files/ downloads/cross_cultural_adaptation_2007.pdf

11. Wynd CA, Schmidt B, Schaefer MA. Two quantitative approaches for estimating content validity. West J Nurs Res. 2003; 25(5):508-18. doi: https://doi.org/10.1177/0193945903252998 
12. Polit DF, Beck CT. The content validity index: are you sure you know what'sbeing reported? Critique and recomendationas. Res Nurs Health. 2006; 29:489-97. doi: https://doi.org/10.1002/ nur.20147

13. Ilha J, Avila LCM, Santo CCE, Swarowsky A. Tradução e adaptação transcultural da versão brasileira da Spinal Cord Independence Measure - Self-Reported Version (brSCIM-SR). Rev Bras Neurol [Internet]. 2016 [citado 2018 mar 6]; 52(1):2-17. Disponível em: http://files.bvs.br/ upload/S/0101-8469/2016/v52n1/a5457.pdf

14. Reis PAM, Carvalho ZMF, Darder JJT, Oriá MOB, Studart RMB, Maniva SJCF. Cross-cultural adaptation of the Quality of Life Index Spinal Cord Injury - Version III. Rev Esc Enferm USP. 2015; 49(3):403-10. doi: http://dx.doi.org/10.1590/ S0080-623420150000300007

15. Aires M, Dal Pizzol FLF, Mocellin D, Rosset I, Morais EP, Paskulin LMG. Cross-cultural adaptation of the Filial Responsibility protocol for use in Brazil. Rev Bras Enferm. 2017; 70(6):1268-76. doi: http:// dx.doi.org/10.1590/0034-7167-2016-0479

16. Bernardo EBR, Catunda HLO, Oliveira MF, Lessa PRA, Ribeiro SG, Pinheiro AKB. Percurso metodológico para tradução e adaptação de escalas na área de saúde sexual e reprodutiva: uma revisão integrativa. Rev Bras Enferm. 2013; 66(4):5928.doi:http://dx.doi.org/10.1590/S003471672013000400019
17. Coura AS, Enders BC, França ISX, Vieira CENK, Dantas DNA, Menezes DJC. Ability for self-care and its association with sociodemographic factors of people with spinal cord injury. Rev Esc Enferm USP. 2013; 47(5):1150-7. doi: http://dx.doi. org/10.1590/S0080-623420130000500020

18. Knihs NS, Schirmer J, Roza BA. Cross-cultural translation of quality instruments in the organ donation process. Acta Paul Enferm. 2014; 27(1):5662. doi: http://dx.doi.org/10.1590/19820194201400012

19. Gomes ALA, Ximenes LB, Mendes ERR, Teixeira OCM, Joventino ES, Javosrki M. Translation and cultural adaptation of the self-efficacy and their child's level of asthma control scale:Brazilian version. Texto Contexto Enferm. 2016; 25(3):e2950015. doi: http:// dx.doi.org/10.1590/0104-07072016002950015

20. Rico ED, Dios HC, Ruch W. Content validity evidences in test development: anapplied perspective. Int J Clin Health Psych [Internet]. 2012 [cited 2018 Mar 06]; 12(3):449-60. Available from: http://www.zora.uzh.ch/id/eprint/64551/1/ ijchp-421.pdf 